\title{
Genetic Analysis of Resistance to Northern Leaf Blight in Maize (Zea mays L.) Reveals its Population Specificity
}

\author{
Shridhar Hegde ${ }^{1 *}$, M. Kumar², N. Meenakshi Ganesan ${ }^{3}$, C. Chinnusamy ${ }^{4}$, \\ A.S. Krishnamoorthy ${ }^{5}$ and Mahantesh Gangashetti ${ }^{6}$
}

${ }^{1}$ Centre for Plant Breeding and Genetics, Tamil Nadu Agricultural University, Coimbatore, Tamil Nadu, India

${ }^{2}$ Department of Cotton, ${ }^{4}$ Department of Agronomy, ${ }^{5}$ Department of Pathology, Tamil Nadu Agricultural University, Coimbatore, Tamil Nadu, India

${ }^{3}$ Directorate of Research, Tamil Nadu Agricultural University, Coimbatore, Tamil Nadu, India

${ }^{6}$ Pioneer Hi-Bred Pvt. Ltd., Kallinayakanahalli 561 213, Gauribidanur, Chikkaballapur, Karnataka, India

*Corresponding author

\section{Keywords}

Maize, Northern leaf blight, Generation means, Duplicate gene

interaction, Reciprocal recurrent selection

Article Info

Accepted:

26 March 2018

Available Online:

10 April 2018

\section{A B S T R A C T}

The present investigation was conducted to understand the genetics of resistance to northern leaf blight in maize through six generation mean analysis in three crosses viz., PH234 X PH84K, PHM6M X PH17H and PHM6M X PHY0Z during kharif 2016-17. The scaling tests and joint scaling tests indicated the inadequacy of additive-dominance model and showed the presence of epistatic gene effects in all the three crosses for northern leaf blight. Further study revealed the importance of additive, dominance and additive $\times$ additive gene effects in the expression of the disease. The magnitude of dominance effect was more compared to additive gene effects. Duplicate gene interaction was evident in the inheritance of northern leaf blight resistance in all the crosses. The study also revealed that genetic architecture of northern leaf blight resistance was population specific. Both, additive and non-additive components were found important suggesting reciprocal recurrent selection as more effective for developing northern leaf blight resistant maize genotypes. 


\section{Introduction}

Maize (Zea mays L.) is one of the most important cereal crops of the world and contributes to food security in most of the developing countries. In India, maize is emerging as the third most important crop after rice and wheat. Its importance lies in the fact that it is not only used for human food and animal feed but at the same time, it is also widely used for corn starch industry, corn oil production, baby corns etc.

One of the major factors limiting the productivity of maize in the tropical Asian region is the increased incidence of insect pests and diseases. Among the various maize diseases, Northern Corn Leaf Blight (NCLB), caused by the pathogen Exserohilum turcicum is a serious threat to maize cultivation worldwide, reportedly causing yield losses of more than 50\% (Raymundo and Hooker 1981; Perkins and Pederson 1987). NCLB is common in areas that have high humidity combined with moderate temperatures in the northeastern United States, in sub-Saharan Africa, and in areas of China, Latin America, and India (Adipala et al., 1995; Dingerdissen et al., 1996). In India, the disease is prevalent in Karnataka, Andhra Pradesh, Bihar, Himachal Pradesh, Maharashtra and other regions (Harlapur et al., 2000).

Several disease management options have been recommended to reduce the impact of NCLB including conventional tillage, crop rotation, foliar fungicide application and planting of resistant hybrids. Among these practices, planting of resistant cultivars can effectively reduce the rate of disease development and is widely recommended. To breed a genotype with high level of resistance to NCLB, the knowledge of gene action involved in the expression of resistant reaction in the material being handled is a pre-requisite to plan an appropriate breeding programme.
Several researchers studied the inheritance of resistance to northern corn leaf blight (Hettiarachchi et al., 2009; Chaudhary and Mani 2010; Poland et al., 2011) and suggested that resistance mechanism is complex and polygenic in nature. Both additive and nonadditive gene effects contributed to the resistance to the disease although additive gene effects were more important (Payak and Sharma 1983; Hettiarachchi et al., 2009). In this connection, an attempt has been made to detect the mode of inheritance of resistance to Northern leaf blight in selected maize cultivars by understanding their reaction and that of segregating lines to the blight and by subjecting the collected data to generation mean analysis.

\section{Materials and Methods}

The present investigation was started during kharif 2015 with the validation of few known inbreds for NCLB resulting in utilization of five inbreds for further study. Among these 5 inbreds, one was found to be resistant (R), one with moderately resistance (MR), one with moderately susceptibility (MS) and two with susceptibility(S). During Rabi 2015, three F1s were produced by crossing R X S, MR X MS and MR X S inbreds. During summer 2016, parents and F1s were planted to generate F2s by selfing $\mathrm{F} 1 \mathrm{~s}$, backcross generations were generated with both the parents (BC1P1 and BC1P2). During Kharif 2016, six generations trial considering $\mathrm{P} 1, \mathrm{P} 2, \mathrm{~F} 1, \mathrm{~F} 2, \mathrm{BC} 1 \mathrm{P} 1$ and $\mathrm{BC} 1 \mathrm{P} 2$ of three populations were planted in Randomized complete design with two replications near Hassan, Karnataka (lat. $13^{0}$ $09^{\prime} \mathrm{N}$ and long. $76^{0} 02^{\prime} \mathrm{E}$ ). Row length of 3 meter with row to row distance 0.6 meter and plant to plant distance $20 \mathrm{~cm}$ was uniformly adopted. Parents and F1s were planted in two rows while $\mathrm{F} 2 \mathrm{~s}$ and $\mathrm{BCs}$ were planted 12 rows per crosses. Appropriate susceptible checks for northern corn leaf blight were sown after every 10th row to assess the disease pressure 
as well as to serve as spreader rows. To ensure uniform disease infestation, artificial inoculation was done by following the procedure detailed by Shekhar and Kumar (2012). Artificial inoculation was made 20 days after sowing between 3.00 to $6.00 \mathrm{PM}$ and inoculation was repeated one week after first inoculation. The northern corn leaf blight severity was recorded at dough stage i.e., 85 days after sowing by visualizing the leaf area using 1-9 scale (Ribeiro et al., 2016, www.pioneer.com), according to lesion spot development in the middle to upper part of leaves on a scale from 1 (Susceptible) to 9 (Resistant) thereby providing for a total of nine classes or categories where score 9: 0-5\% leaf loss, score 8: 6-10\% leaf loss, score 7: 1124\% leaf loss, score 6: $25-44 \%$ leaf loss, score 5: 45-55\% leaf loss, score 4: 56-66\% leaf loss, score 3: $67-77 \%$ leaf loss, score 2: 78-88\% leaf loss and score 1: 89-100 leaf loss.

\section{Statistical analysis}

The data were subjected to generation mean analysis for the estimation of gene effects using six parameter model as suggested by Hayman (1958) and Jinks and Jones (1958). Mather (1949) scaling tests (A, B, C and D) were used to detect the presence or absence of epistasis. Joint scaling test of Cavali (1952) was used to estimate gene effects when additive-dominance model was inadequate.

\section{Results and Discussion}

The mean values along with standard error and variance and variance of means of six generations (P1, P2, F1, F2, BC1P1 and BC1P2) of maize in respect of Northern leaf blight of maize are tabulated (Table 1) and briefly presented below. Disease severity score was varying from 8.2 (PH234) to 2.1 (PHY0Z) among parents, while F1s recorded intermediate scores. In F1s, disease severity ranged from 4.3 ( $\mathrm{PH} 234 \mathrm{X} \mathrm{PH} 84 \mathrm{~K})$ to 3
(PHM6M X PHY0Z). Among the segregating populations, means of $\mathrm{F} 2 \mathrm{~s}$ of three crosses were 4.5 (PH234 X PH84K), 4.38 (PHM6M X PH17H) and 3.06 (PHM6M X PHY0Z) which were intermediate of their respective $\mathrm{BC} 1 \mathrm{P} 1$ $(6.18,4.92,4.52$ respectively) and $\mathrm{BC} 1 \mathrm{P} 2$ (3.76, 3.66, 3.52 respectively) populations. This indicates that the parents selected for the study were highly diverse in nature with respect to disease response to northern leaf blight.

The mean and variance of six generations viz., $\mathrm{P} 1, \mathrm{P} 2, \mathrm{~F} 1, \mathrm{~F} 2, \mathrm{BC} 1 \mathrm{P} 1$ and $\mathrm{BC} 1 \mathrm{P} 2$ of the three crosses in respect of Northern leaf blight disease score were subjected to Mather's scaling tests and Cavallis joint scaling test (Table 2 and 3) to check the presence or absence of gene interaction in the inheritance of northern corn leaf blight. The scaling tests $\mathrm{B}$ and D were significant in crosses $\mathrm{PH} 234 \mathrm{X}$ PH84K and PHM6M X PHY0Z and scaling test $\mathrm{B}$ was significant in cross PHM6M X $\mathrm{PH} 17 \mathrm{H}$ indicating the inadequacy of additivedominance model which was further confirmed by significance of additive and dominance components in joint scaling test suggesting the importance of both additive and dominance gene effects in the inheritance of resistance to northern corn leaf blight in these crosses. The disease reaction is quantitatively inherited as indicated by the highly significant mean effects $[\mathrm{m}]$ in the crosses.

After observing the failure of additivedominance model, a perfect fit solution (Mather and Jinks, 1971; Jinks and Jones, 1958) was fitted to estimate the magnitude and direction of digenic interaction effects for all the three crosses (Table 4). The additive $\left[d^{\wedge}\right]$, dominance $\left[h^{\wedge}\right]$, additive $\mathrm{x}$ additive $\left[i^{\wedge}\right]$, interaction gene effects were significant and positive in crosses $\mathrm{PH} 234 \mathrm{X} \mathrm{PH} 84 \mathrm{~K}$ and PHM6M X PHY0Z while, additive $\left[d^{\wedge}\right]$ gene effect was significantly positive in PHM6M X $\mathrm{PH} 17 \mathrm{H}$ cross. 
Table.1 Estimates of means of generations with their standard error, variance and variance of mean for response to northern corn leaf blight

\begin{tabular}{|c|c|c|c|c|}
\hline \multicolumn{2}{|c|}{ Parents/Generations } & \multicolumn{3}{|c|}{ Northern Leaf Blight } \\
\hline & & Mean \pm SE & Variance & Var. of Mean \\
\hline \multirow[t]{5}{*}{ Parents (10) } & PH234 & $8.2 \pm 0.133$ & 0.178 & 0.018 \\
\hline & PH84K & $2.2 \pm 0.133$ & 0.178 & 0.018 \\
\hline & PHM6M & $5.4 \pm 0.163$ & 0.266 & 0.026 \\
\hline & PH17H & $4.2 \pm 0.133$ & 0.177 & 0.017 \\
\hline & PHY0Z & $2.1 \pm 0.179$ & 0.322 & 0.032 \\
\hline \multirow[t]{3}{*}{ F1 (10) } & PH234 X PH84K & $4.3 \pm 0.152$ & 0.233 & 0.023 \\
\hline & PHM6M X PH17H & $4.2 \pm 0.133$ & 0.177 & 0.017 \\
\hline & PHM6M X PHY0Z & $3 \pm 0.149$ & 0.222 & 0.022 \\
\hline \multirow[t]{3}{*}{ F2 (100) } & PH234 X PH84K & $4.5 \pm 0.106$ & 1.141 & 0.011 \\
\hline & PHM6M X PH17H & $4.38 \pm 0.123$ & 1.531 & 0.015 \\
\hline & PHM6M X PHY0Z & $3.06 \pm 0.115$ & 1.329 & 0.013 \\
\hline \multirow[t]{3}{*}{ BC1P1 (50) } & PH234 X (PH234 X PH84K) & $6.18 \pm 0.130$ & 0.844 & 0.016 \\
\hline & PHM6M X (PHM6M X PH17H) & $4.92 \pm 0.12$ & 0.728 & 0.014 \\
\hline & PHM6M X (PHM6M X PHY0Z) & $4.52 \pm 0.134$ & 0.907 & 0.018 \\
\hline \multirow[t]{3}{*}{ BC1P2 (50) } & PH84K X (PH234 X PH84K) & $3.76 \pm 0.123$ & 0.757 & 0.015 \\
\hline & PH17H X (PHM6M X PH17H) & $3.66 \pm 0.101$ & 0.514 & 0.0103 \\
\hline & PHY0Z X (PHM6M X PHY0Z) & $3.52 \pm 0.104$ & 0.54 & 0.0108 \\
\hline
\end{tabular}


Table.2 Estimates of Scaling Test for northern leaf blight scores of different generations

\begin{tabular}{|c|l|c|c|c|c|c|}
\hline Sr no & \multicolumn{1}{|c|}{ Cross } & $\begin{array}{c}\text { Parent based } \\
\text { Disease Reaction }\end{array}$ & A & B & C \\
\hline $\mathbf{1}$ & PH234 X PH84K & R X S & $-0.140 \pm 0.109$ & $1.020^{* *} \pm 0.102$ & $-1.000 \pm 0.312$ & $-0.940 * * \pm 0.078$ \\
\hline $\mathbf{2}$ & PHM6M X PH17H & MR XMS & $0.240 \pm 0.103$ & $-1.080^{* *} \pm 0.077$ & $-0.480 \pm 0.361$ & $0.180 \pm 0.086$ \\
\hline $\mathbf{3}$ & PHM6M X PHY0Z & MR X S & $0.640 \pm 0.122$ & $1.940^{* *} \pm 0.098$ & $-1.260^{*} \pm 0.361$ & $-1.920^{* *} \pm 0.082$ \\
\hline
\end{tabular}

*Significant at $5 \%$ level of significance, $* *$ Significant at $1 \%$ level of significance.

Table.3 Estimates of components of generation means and Test of adequacy of additive-dominance model for inheritance of northern leaf blight

\begin{tabular}{|c|l|c|c|c|c|}
$\begin{array}{c}\text { Sr } \\
\text { no }\end{array}$ & \multicolumn{1}{|c|}{ Cross } & $\begin{array}{c}\text { Parent based } \\
\text { disease reaction }\end{array}$ & $($ M) Mean & (d) Add & (h) dom \\
\hline $\mathbf{1}$ & PH234 X PH84K & R X S & $4.500^{* *} \pm 0.107$ & $2.420 * * \pm 0.179$ & $0.980 * \pm 0.343$ \\
\hline $\mathbf{2}$ & PHM6M X PH17H & MR XMS & $4.380^{* *} \pm 0.124$ & $1.260^{* *} \pm 0.158$ & $-0.960 * \pm 0.611$ \\
\hline $\mathbf{3}$ & PHM6M X PHY0Z & MR X S & $3.060^{* *} \pm 0.115$ & $1.000^{* *} \pm 0.170$ & $3.090^{* *} \pm 0.605$ \\
\hline
\end{tabular}

*Significant at 5\% level of significance, ${ }^{*}$ Significant at $1 \%$ level of significance.

Table.4 Estimates of components of generation means based on perfect fit solution (Joint Scaling Test) for northern leaf blight

\begin{tabular}{|c|c|c|c|c|c|c|c|c|}
\hline CROSS & $\begin{array}{c}\text { HYPO. } \\
\text { DR }\end{array}$ & $M$ mean & $d^{\wedge}$ Add & $h^{\wedge}$ Dom & $i^{\wedge} A d d * A d d$ & $j^{\wedge} A d d * D o m$ & $l^{\wedge}$ Dom * Dom & $\begin{array}{c}\text { Gene } \\
\text { Action }\end{array}$ \\
\hline PH234 X PH84K & R X S & $3.320 * * \pm 0.565$ & $3.000 * * \pm 0.094$ & $3.740 * * \pm 1.410$ & $\begin{array}{c}1.880 * * \pm \\
0.557\end{array}$ & $-0.580 * * \pm 0.202$ & $-2.76^{* *} \pm 0.907$ & Duplicate \\
\hline $\begin{array}{l}\text { PHM6M X } \\
\text { PH17H }\end{array}$ & MR XMS & $5.160 * * \pm 0.596$ & $0.600 * * \pm 0.105$ & $-2.160 \pm 1.411$ & $-0.360 \pm 0.586$ & $0.660 * * \pm 0.189$ & $1.200^{*} \pm 0.870$ & Duplicate \\
\hline $\begin{array}{l}\text { PHM6M X } \\
\text { PHY0Z }\end{array}$ & MR X S & $-0.090 \pm 0.585$ & $1.650 * * \pm 0.121$ & $9.510 * * \pm 1.431$ & $\begin{array}{c}3.840 * * \pm \\
0.573\end{array}$ & $-0.650 * * \pm 0.209$ & $-6.420 * * \pm 0.907$ & Duplicate \\
\hline
\end{tabular}

*Significant at 5\% level of significance, $* *$ Significant at $1 \%$ level of significance. 
The additive $\mathrm{x}$ dominance $\left[j^{\wedge}\right]$ and dominance $\mathrm{x}$ dominance $\left[l^{\wedge}\right]$ interactions were negatively significant in crosses $\mathrm{PH} 234 \mathrm{X}$ PH84K and PHM6M X PHY0Z and positively significant in cross PHM6M X PH17H. This reveals that genetic architecture of northern leaf blight resistance was population specific. Ranganatha et al., (2017) also reported population specific genetic control of the disease. The magnitude of dominance effect was more compared to additive gene effect. Opposite signs of $\left[h^{\wedge}\right]$ and $\left[l^{\wedge}\right]$ components indicated the presence of duplicate gene interaction in the genetic control of Northern leaf blight in all the three crosses which emphasized the importance of bi-parental mating or recurrent selection programs to bring out desirable genetic improvements. Hettiarachchi et al., (2009) also reported additive, additive $\mathrm{x}$ dominance and dominance $\mathrm{x}$ dominance gene effects for resistance to northern corn leaf blight. Duplicate gene interaction based on the significant opposite signs of $\left[h^{\wedge}\right]$ and $\left[l^{\wedge}\right]$ components was involved in the genetic control of NCLB in both crosses (Hettiarachchi et al., 2009). The duplicate epistasis generally hinders the improvement through selection and also placing a limitation on exploitation of higher magnitude of dominance and dominance $\times$ dominance gene effects. However, significant role of dominance variance along with duplicate epistasis in the inheritance of resistance favours the development of single cross hybrids (Patil et al., 2016). The observed differences in the crosses could be attributed to change in gene frequencies and proportion of dominance and recessive genes possessed by parents (Viana et al., 1999).

It is evident from the data that resistance to northern corn leaf blight was controlled by duplicate gene interaction. This indicates that the dominant genes produce the same disease expression whether they are alone or in pairs.
The duplicate epistasis generally hinders the improvement through selection and also placing a limitation on exploitation of higher magnitude of dominance and dominance $x$ dominance gene effects (Ranganatha et al., 2017). This favors the development of single cross hybrids to exploit dominance and duplicate gene action (Patil et al., 2016). However, population specific epistasis does exist and hence breeding methods to be adopted for the improvement of each population needs to be different based on the population make up.

\section{References}

Adipala, E., Takan, J. P. and Ogenga-Latigo, M. W., 1995. Effect of planting density of maize on the progress and spread of Northern leaf blight from Exserohilum turcicum infested residue source. Europ. J. Plant Pathol., 101: 25-33.

Cavalli, L. L., 1952. An analysis of linkage in quantitative inheritance. In: "Quantitative inheritance" (Ed). E. C. Rieve and C. H. Waddington, HMSO, London, pp. 135-144.

Chaudhary, B. and Mani, V. P., 2010, Genetic analysis of resistance to Turcicum Leaf Blight in semi-temperate early maturing genotypes of maize (Zea mays). Indian J. Genet., 70(1): 65-70.

Dingerdissen, A. L., Geiger, H. H., Lee, M., Schechert, A. and Welz, H. G., 1996, Interval mapping of genes for quantitative resistance of maize to Setosphaeria turcica, cause of northern leaf blight, in a tropical environment. Mol. Breed., 2: 143-156.

Harlapur S. I., Wali M. C., Anahosur K. H. and Muralikrishna. 2000. Survey and surveillance of maize diseases in North Karnataka. Karnataka J. Agric. Sci. 13(3): 750-751.

Hayman, B. I. 1958. The separation of epistatic from additive and dominance 
variation in generation means. Heredity, 12: 371- 390.

Hettiarachchi, K., Prasanna, B. M., Rajan, A., Singh, O. N., Gowda, K.T.P., Pant, S. K. and Kumar, S., 2009, Generation mean analysis of turcicum leaf blight resistance in maize. Indian J. Genet. 69: 102-108.

Jinks, J. L. and Jones, R. M. 1958. Estimation of the components of heterosis. Genetics. 43(2): 223-234.

Mather, K. and Jinks, J. L., 1971, Biometrical genetics. PB: Chapman and Hall, London.

Mather, K., 1949, Biometrical Genetics. Dover Publication Inc., New York.

Patil K. H., Mahajan R. C. and Lekha Rani C. 2016. Generation mean analysis for grain yield attributing traits in maize (Zea mays L.), Green Farming, 7(2): 277-282.

Payak, M. M. and Sharma, R. C., 1983, Disease rating scales in maize in India. In: Techniques of Scoring for Resistance to Important Diseases of Maize. All India Coordinated Maize Improvement Project, IARI, New Delhi, pp. 1-4.

Perkins, J. M., and W. L. Pederson, 1987 Disease development and yield losses associated with northern corn leaf blight on corn. Plant Dis. 71: 940-943.
Poland, J. A., Bradbury, P. J., Buckler, E. S. and Nelson, R. J., 2011, Genome-wide nested association mapping of quantitative resistance to northern leaf blight in maize. Proc. Natl. Acad. Sci., 108: 6893-6898.

Ranganatha H. M., Lohithaswa H. C., and Pandravada, A. S., 2017. Understanding the genetic architecture of resistance to northern corn leaf blight and southern corn rust in maize (Zea mays L.).Indian J. Genet. 77(3): 357-363.

Raymundo, A. D., and A. L. Hooker, 1981. Measuring the relationship between northern corn leaf blight and yield losses. Plant Dis. 65: 325-327.

Ribeiro R.M., do Amaral, A.T., Pena, G.F., Vivas, M., Kurosawa, R.N. and Goncalves, L.S.A., 2016. History of northern corn leaf blight disease in the seventh cycle of recurrent selection of an UENF-14 popcorn population. Acta Scientiarum, Argon, 38(4): 447-455.

Shekhar M. and Kumar S. 2012. Inoculation methods and disease rating scales for maize diseases. In: Directorate of Maize, ICAR, New Delhi, 2-16.

Viana J. M. S., Cruz C. D. and Cardoso A. A. 1999. Theory and analysis of partial diallel crosses. Genet. Mol. Biol., 22: 591-599.

\section{How to cite this article:}

Shridhar Hegde, M. Kumar, N. Meenakshi Ganesan, C. Chinnusamy, A.S. Krishnamoorthy and Mahantesh Gangashetti. 2018. Genetic Analysis of Resistance to Northern Leaf Blight in Maize (Zea mays L.) Reveals its Population Specificity. Int.J.Curr.Microbiol.App.Sci. 7(04): 30843090. doi: https://doi.org/10.20546/ijcmas.2018.704.350 